\title{
Factors Affecting E-Service Satisfaction
}

\author{
Mohammed Mufaddy Al-Kasasbeh ${ }^{1}$, Subhasish Dasgupta ${ }^{2}$ \\ and Abeer Hmoud AL-Faouri ${ }^{3}$ \\ ${ }^{1}$ Business Management Dept., Amman Arab University, Jordan \\ ${ }^{2}$ Information Systems \& Technology Management Dept, George Washington University, USA \\ ${ }^{3}$ Management Information Systems Dept., Petra University, Jordan
}

\begin{abstract}
User satisfaction is an important predictor of online consumer behavior and the success of a web-based system. If customers are satisfied with the services received through the online system, it is likely they will keep using the system. To examine factors affecting user satisfaction with e-services, a questionnaire was distributed to a random sample of (615) students out of (5918) at Petra University in Jordan to explore their perceptions. Regression analysis was conducted to test the hypotheses. The results indicated that website design, navigation, and personalization were found to be predictors of e-service satisfaction. The results of this study provide a comprehensive set of implications for practitioners and researchers. This study shows how the website design, navigation, and personalization play a crucial role in the overall evaluation of e-service satisfaction. Management of universities need to be aware that a bad experience with website design, navigation, and personalization can affect satisfaction, if a student has a bad experience regarding interactivity, customization, or website design, then a student might make an overall e-service judgment even before a transaction can take place. If customers believe that an organization's website is hard to use, poorly designed, and doesn't take into consideration distinguished services for each user, then customers are likely to move to other organizations' websites.
\end{abstract}

Key Words: E-Service, User Satisfaction, Website Design, Navigation, Personalization, Petra University in Jordan.

\section{Introduction}

Research has consistently demonstrated that service quality elicits a host of positive attitudinal responses (Tan and Benbasat, 2009) such as loyalty (Cristobal, Flavian and Guinalıu, 2007; Gefen, 2002; Reichheld and Schefter, 2000), trust (AL-Faouri and AL-Kasasbeh, 2010; Hong-Youl, 2004; Gefen, 2000) and satisfaction (Cenfetelli et al., 2008; Cristobal, Flavian and Guinalıu, 2007; Cheung, and Lee, 2004/2005; Cronin, Brady and Hult, 2000) from customers. With the rapid global growth in electronic commerce, businesses are attempting to gain a competitive advantage by using ecommerce to interact with customers.
Businesses with the most experience and success in using e-commerce are beginning to realize that the key determinants of success or failure are not merely website presence and low price but also include electronic service quality (Zeithaml, 2002; Yang, 2001). However, as today's products and services are radically shifted to digital form and delivered through the internet, the most visible information technology applications will also move to this new platform (Sukasame, 2005). Santos (2003) defined e-service quality as overall customer assessment and judgment of eservice delivery in the virtual marketplace (Lee and Lin, 2005). which permits unrestricted use, distribution, and reproduction in any medium, provided that original work is properly cited. Contact author: Mohammed Mufaddy Al-Kasasbeh e-maill: mkasasbeh2002@yahoo.com 
E-service quality can help firms to differentiate themselves by offering enhanced satisfaction, encouraging repeat purchases and building loyalty (Zeithaml, Parasuraman and Malhotra, 2002). Each service element in e-commerce offers an opportunity for such differentiation. Eservice quality may also affect customers' emotional responses such as liking, joy, pride, dislike and frustration (Noel, Zhang and Lam, 2010; Ethier et al. 2006).

The main function of a business website is to inform consumers about the company and its products or services (Hallerman, 2009). Analysis of website performance in terms of design criteria and other related factors became an important area of enquiry (Tarafdar and Zhang, 2008). Appropriate website design ultimately enables organizations accomplish their ebusiness activities with greater success (Wakefield, Stocks and Wilder, 2004). Therefore, designing an effective website that attracts as well as retains web users has become an important task (Tarafdar and Zhang, 2008).

Navigation in a website should make users feel comfortable when browsing it and make the user feel so intensely involved in the activity that the experience becomes intrinsically enjoyable, and this in turn increases the probability of a transaction being completed (Hernandez, Jimenez and Martin, 2009).

Personalization makes it easy for customers to use the website (Palmer, 2002). Kim and Lee (2006) assured that recognizing key differences in customer perceptions of website quality across countries is critical for a company wishing to satisfy its customers.

This study is organized as follows. First, we review relevant literature to develop an exploratory model relating website design, navigation, personalization to e-service satisfaction, and propose the research hypotheses. Second, we describe the research methodology and sample characteristics. Third, we present the data analysis and results. Finally, the paper ends with a conclusion and a discussion of limitations, practical implications and avenues for future research.

\section{Literature Review and Hypotheses Development}

In this section we present a literature review that covers all the research areas of interest to this study: e-service satisfaction, website design, navigation, and personalization. The literature review provides the foundation for developing hypotheses for this study.

\section{E-Service Satisfaction}

In our review of relevant literature on the topic we found that there are many different definitions for terms related to service quality such as online service quality and website service quality (Wahab et al., 2010). Electronic service quality was introduced as a new concept in 2002. Zeithaml, Parasuraman, and Malhotra (2002) introduced the concept of e-service quality, which is defined as "the extent to which a website facilitates efficient and effective shopping, purchasing and delivery of products and services".

User satisfaction is an important predictor of online consumer behavior and the success of a web-based system. If customers are satisfied with the services received through the online system, it is likely they will keep using the system. On the other hand, if customers get frustrated and dissatisfied with the online system, they would be unlikely to come back for a visit (Xiao and Dasgupta, 2005).

The quality of a customer's experience with e-business is dependent on thoughtful design, streamlined business processes, carefully respected policies, good customer service and excellent execution (Cheung and Lee, 2004/2005). Satisfaction is an affective state that is the emotional reaction to a product or service experience (Cristobal, Flavian and Guinalıu, 2007).

However, there is still no widely accepted consensus on the satisfaction construct. It is important to note that a conclusive set of antecedent variables of consumer 
satisfaction with consumer-based ecommerce is missing. The internet was responsible for the creation of a new concept, e-satisfaction. Hise and Szymanski (2000) define e-satisfaction as the consumers' judgment of their internet retail experience as compared to their experiences with traditional retail stores.

Evanschitzky et al. (2004) argue that the most obvious difference between traditional and electronic retail services is the replacement of human-to-human interaction with human-to-machine interaction and therefore, new or modified approaches to conceptualizing and measuring satisfaction may be needed for e-commerce settings. Accordingly, esatisfaction can be defined as the overall affective evaluation a user has regarding his or her experience related with the website. For success in e-commerce, retailers need to provide high quality websites that attract and retain shoppers (Kim and Lee, 2006; Loiacono, Chen and Goodhue, 2002).

Janda, Trocchia and Gwinner (2002) develop four dimensions of measuring eservice quality including access, security, sensation and information/content, Zeithaml (2002) also develops a framework consisting of eleven dimensions to be used in evaluating the delivery of eservice quality, which includes access, ease of navigation, efficiency, flexibility, reliability, personalization, security/ privacy, responsiveness, assurance/ trust, site aesthetics, and price knowledge. Some of those factors have been studied by researchers to identify the e-customer satisfaction or success of the internetbased commerce.

Therefore, in the light of literature review, and based on e-learning applications, the researchers in this study identified that eservice satisfaction is affected by three specific variables which are: website design, navigation, and personalization.

\section{Website Design}

The influence of website design on eservice performance has been studied extensively. For instance, Cho and Park (2001) conducted an empirical research of a sample of 435 internet users to examine the e-commerce user-consumer satisfaction index for internet shopping. They found that the customer satisfaction is assessed using the quality of website design. A past empirical study found that website design factors are strong predictors of customer quality judgments, satisfaction, and loyalty for internet retailers (Wolfmbarger and Gilly, 2003).

The results of prior empirical studies found that web user's intention to revisit the website was significantly influenced by his/her positive attitude towards the website (Chuan and Chuan, 2007; Vijayasarathy, 2004; Chen, Gillenson and Sherrell, 2002; Moon and Kim, 2001; Lin and Lu, 2000). According to Loiacono, Chen and Goodhue (2002) the time it takes to download a webpage, the graphical and textual features that affect the user's sense of ease or comfort with the website and the aesthetics of a website should be considered in website design. A good strategy includes knowing what to emphasize on a website, presenting with consistency, and using up-to-date technology (Tan, Tung and $\mathrm{Xu}, 2009$ ).

Two of the common rules for web design are: 1) a dominant visual should be used as an eye-catcher to attract visitors' attention, and 2) the dominant visual must be above the expectations (McIntire, 2008). Many bloggers have suggested that the dominant video, if there is one, on the home page should be put above the expectations on a webpage to attract visitors.

In this study, "website design" constructs deals with the visual presentation of the website, the use of graphics, colors, photographs, various font types to improve the look and feel of the website and other related characteristics. Based on our review of previous studies, we present our first hypothesis as follows.

H1: Website design has a significant influence on e-service satisfaction. 


\section{Website Navigation}

Website use characteristic is important and it refers to the ease with which a user can browse a website. (Boudhayan et al., 2009; Hernandez, Jimenez and Martin, 2009; Tarafdar and Zhang, 2006; Loiacono, Chen and Goodhue, 2002). Navigation depends on the manner in which the information is organized and arranged, in terms of design, layout and sequencing (Tarafdar and Zhang, 2006), effectiveness of hyperlinks and the overall organization of the information (Nielsen, 2000).

Navigation deals with the evaluation of links to needed information. Nielsen (2000) suggested that organization and navigation are important to outcomes. Madu and Madu (2002) urged that consumers can be easily turned off when the website is not easy to navigate. Jayawardhena and Foley (2000) advocated that ease of navigation is critical to enhancing customer satisfaction with internet banking websites.

Cheung and Lee (2004/2005) believe the effect of a negative website attribute performance (or poor system quality) on satisfaction will be more significant than positive attribute performance. Navigation or interactivity was defined as the ability to allow the user and the company to communicate directly with each other without concern for distance or time (Barnes and Vidgen, 2002).

Ribbink et al. (2004) argued that communication is part of e-quality and is an antecedent to satisfaction. Two way communication options with the website provide timely feedback and facilitate information exchange (Boudhayan, et al., 2009). Cyr (2008) assured that even if detailed information is put on the website the customer may be leaving the website if he finds it difficult to search for the information he wants.

After reviewing the related studies, the researchers proposed the following hypothesis:
H2: Website navigation has a significant influence on e-service satisfaction.

\section{Website Personalization}

Personalization or customization has become significant as a result of the increase in business to customer transactions. Customization characteristic is also an important aspect of website quality (Kim and Lee, 2006). Customization was defined as the ability of websites to present information tailored to individual requirements (Kim and Lee, 2006), or the capability to provide the customized information requirements of specific groups of customers (Greer and Murtaza, 2003; Chen and Hitt, 2002). Customization capabilities such as "My Yahoo" features help customers to easily return to specific information and interact with the website (Palmer, 2002; Novak, Hofftnan and Yung, 2000).

Kim and Lee (2006) proposed that the property of customization is a critical element and can considerably influence the performance of the website. The designers of websites should take into serious consideration the wide variety of the people who visit the websites in order to satisfy their expectations.

As a result, it is quite obvious that the evaluation of website should be a major tool not only during its design phase but also during its lifetime maintenance as it is essential for determining whether it meets the needs of its virtual visitors (Pallas and Economide, 2008).

The third hypothesis of this study is:

H3: Website personalization has a significant influence on e-service satisfaction.

Based on the literature review, we propose the following research theoretical framework. 


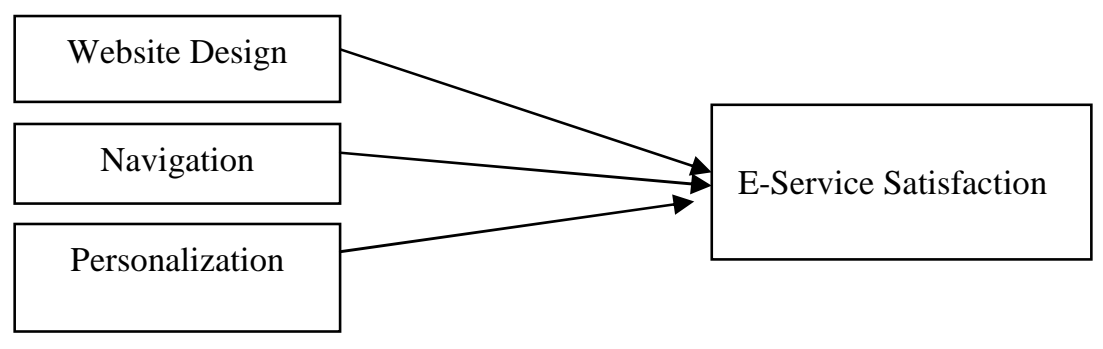

Independent Variables

Dependent Variable

\section{Figure 1: The Research Theoretical Framework}

\section{Methodology}

A questionnaire was developed to explore the perceptions of students regarding a university's website design, navigation, personalization and e-service satisfaction. All items of the questionnaire were adopted from previous researches. Respondents were asked to answer questions on a five-point Likert scale, which $1=$ strongly disagree, $2=$ disagree, $3=$ neutral, $4=$ agree and $5=$ strongly agree.

\section{Sample}

A random sample of (615) students out of (5918) at Petra University in Jordan was used in this study. A questionnaire was distributed during the second semester of the academic year 2009/2010. Petra University was chosen because it has a strategic plan for quality assurance and a strategic vision, "to be the University of Choice, in Jordan and the region, for learners and scholars" (http://www.uop.edu.jo, 2010).
Petra University as well as receives high ranks locally and regionally based on Web of World Universities Ranking (Webometrics)(http://www.webometrics.i nfo, 2010). Petra University is in the Top 100 Arab-World Universities List and the Top Jordanian Universities List. PetraUniversity has achieved excellent results in the Web of World Universities Ranking (Webometrics), which is announced every six months, where Petra University was ranked first among the private universities of Jordan, in the evaluation, announced in July 2010.

\section{Respondents' Characteristics}

The respondents consisted of (61.6 percent) males and (38.4 percent) females distributed on (5) years academic levels. More than (80 percent) of respondents were Jordanian, and approximately (60 percent) of them were studying at School of Administrative and Financial Sciences, and their Cumulative Grade Point Average (GPA) ranged from 2.67 to less than 3 out of 4. The majority of them (95.6 percent) have a high or moderate level of internet usage skill. And (77.1 percent) of them navigate the internet at least once daily. 
Data Analysis and Results

Table 2: Factor Loadings and Reliability of the Constructs

\begin{tabular}{|c|c|c|c|c|}
\hline $\begin{array}{l}\text { Alpha } \\
\text { Cronbach }\end{array}$ & 0.865 & 0.816 & 0.814 & 0.849 \\
\hline Items & Design & Navigation & Personalization & E-Service Sat \\
\hline Design1 & .611 & & & \\
\hline Design2 & .643 & & & \\
\hline Design3 & 613 & & & \\
\hline Design 4 & .587 & & & \\
\hline Design 5 & .559 & & & \\
\hline Design 6 & .581 & & & \\
\hline Design 7 & .526 & & & \\
\hline Design 8 & .592 & & & \\
\hline Design 9 & .587 & & & \\
\hline Design 10 & .625 & & & \\
\hline Design 11 & .578 & & & \\
\hline Design 12 & .625 & & & \\
\hline Design 13 & 601 & & & \\
\hline Design 14 & 613 & & & \\
\hline Design 15 & .504 & & & \\
\hline Navigation16 & & .555 & & \\
\hline Navigation17 & & .575 & & \\
\hline Navigation18 & & .510 & & \\
\hline Navigation19 & & .512 & & \\
\hline Navigation20 & & .653 & & \\
\hline Navigation21 & & .627 & & \\
\hline Navigation22 & & .648 & & \\
\hline Navigation23 & & .674 & & \\
\hline Navigation24 & & .696 & & \\
\hline Navigation25 & & .670 & & \\
\hline Personalization & & & .657 & \\
\hline 26 & & & .816 & \\
\hline Personalization & & & $\begin{array}{l}.838 \\
769\end{array}$ & \\
\hline $\begin{array}{c}27 \\
\text { Personalization }\end{array}$ & & & $\begin{array}{l}.769 \\
.709\end{array}$ & \\
\hline 28 & & & & \\
\hline $\begin{array}{c}\text { Personalization } \\
29\end{array}$ & & & & \\
\hline $\begin{array}{c}\text { Personalization } \\
30\end{array}$ & & & & \\
\hline E-service Sat31 & & & & .587 \\
\hline E-service Sat32 & & & & .589 \\
\hline E-service Sat33 & & & & .556 \\
\hline E-service Sat34 & & & & .568 \\
\hline E-service Sat35 & & & & .681 \\
\hline E-service Sat36 & & & & .720 \\
\hline E-service Sat37 & & & & .681 \\
\hline E-service Sat38 & & & & .709 \\
\hline E-service Sat39 & & & & .751 \\
\hline E-service Sat 40 & & & & .686 \\
\hline
\end{tabular}

All factor loadings are significant at $\mathrm{P}$-value $<0.05$. 
Statistical analysis consisted of three steps. First, factor analysis using varimax rotation method was conducted to extract constructs and determine variance explained. As for threshold of primary loading, the researchers adopted 0.5 as threshold, as Chen et al. (2000) adopted in their study.

The results of the factor analysis revealed four constructs. Those results had factor loadings that ranged from 0.504 to 0.838 as shown in the table 1.

The reliability of the questionnaire was tested by computing coefficient alpha. The results indicated that Cronbach alpha reliability for the constructs ranged from 0.814 to 0.865 , indicating reliability of the items measuring the underlying constructs exceeding an acceptable level of reliability $(\alpha \geq 0.70$ ) (Sekaran and Bougie, 2010). Table 2 shows the reliability of the constructs.

Second, the multicollinearity of variables was checked by identifying correlations equal to or greater than 0.70. Finally, the researchers ran regression model to test the hypotheses.

\section{Correlation Analysis}

Pearson correlation was conducted to determine the strength and direction of the relationship between variables. The values of the correlation coefficients ( $r$ ) given in the table 1 indicate the strength of the relationship between variables with correlation values less than 0.70 and significant at the $\mathrm{p}<0.0$ ). According to Pallant, (2001) the correlation between predictor and dependent variables must be below 0.70 . If the score is more than 0.7 , the variables must be deleted from the study.

Moreover, the computed variable inflation factors (VIFs) among the independent variables ranged from 1.650 to 1.996 as shown in table 2, which are acceptable. Hair et al. (1995) suggest 10.0 as the cut-off score for acceptable VIF.

Table 2: Correlation Matrix

\begin{tabular}{|l|l|l|l|}
\hline Variable & $\begin{array}{l}\text { E-service } \\
\text { satisfaction }\end{array}$ & Design & Navigation \\
\hline Design & $0.541^{* *}$ & & \\
\hline Navigation & $0.559^{* *}$ & $0.631^{* *}$ & \\
\hline Personalization & $0.510^{* *}$ & $0.521^{* *}$ & $0.600^{* *}$ \\
\hline${ }^{* *}$ Correlation is significant at the $P<0.0^{\prime}(2$-tailed).
\end{tabular}

\section{Regression Analysis}

Regression model was used for testing the hypotheses. Results indicated that there was significant influence for the independent variables in explaining the construct e-service satisfaction as follows; design (Beta $=0.262, \mathrm{P}<0.001$ ), navigation (Beta $=0.265, \quad \mathrm{P}<0.0 .1$ ) and personalization (Beta $=0.215, \mathrm{P}<0.0 \cdot 1)$. Thus, hypotheses 1,2 and 3 were supported. Table 3 shows the results of regression analysis. These results are consistent with the findings in prior studies as follows:

The results of Noel, Zhang and Lam (2010) indicated that website design and personalization are significant predictors of customer satisfaction. Also, the analytical results of Lee and Lin (2005) showed that the dimensions of website design affect overall service quality and customer satisfaction, while the personalization dimension is not significantly related to overall service quality and customer satisfaction. 
Moreover, the findings of Cristobal, Flavian and Guinalıu (2007) indicated that perceived quality is a multidimensional construct; (web design, assurance, customer service and order management), which affect satisfaction. And the empirical study of Wolfmbarger and Gilly (2003) found that website design factors are strong predictors of customer quality judgments, satisfaction and loyalty for internet retailers. As well as, the empirical research of Cho and Park (2001) indicated that the customer satisfaction is assessed using the quality of website design.
The results provided bye Cheung and Lee (2004/2005) showed that the positive performance on information understandability and system navigation had a more significant impact on satisfaction than their negative performance. Furthermore, findings of Ribbink et al. (2004) indicated that equality dimensions (ease of use, responsiveness, and customization) are found to indirectly affect e-loyalty, via satisfaction.

Table 3: Results of Regression Analysis and Variable Inflation Factors (VIF)

\begin{tabular}{|c|c|c|c|c|c|c|c|}
\hline \multirow[t]{2}{*}{ Model } & \multicolumn{2}{|c|}{$\begin{array}{l}\text { Unstandard } \\
\text { ized } \\
\text { Coefficients }\end{array}$} & \multirow{2}{*}{$\begin{array}{l}\text { Standardi } \\
\text { zed } \\
\text { Coefficien } \\
\text { ts } \\
\text { Beta }\end{array}$} & \multirow[t]{2}{*}{$\mathbf{t}$} & \multirow[t]{2}{*}{ Sig. } & \multicolumn{2}{|c|}{$\begin{array}{l}\text { Collinearity } \\
\text { Statistics }\end{array}$} \\
\hline & B & $\begin{array}{l}\text { Std. } \\
\text { Erro } \\
\text { r }\end{array}$ & & & & $\begin{array}{l}\text { Toleran } \\
\text { ce }\end{array}$ & VIF \\
\hline 1 (Constant) & $\begin{array}{l}0.99 \\
7\end{array}$ & 0.147 & & $\begin{array}{l}6.79 \\
4\end{array}$ & $\begin{array}{l}.00 \\
0\end{array}$ & & \\
\hline Design & $\begin{array}{l}0.31 \\
3\end{array}$ & 0.050 & 0.262 & $\begin{array}{l}6.30 \\
5\end{array}$ & $\begin{array}{l}.00 \\
0\end{array}$ & 0.570 & $\begin{array}{l}1.75 \\
4\end{array}$ \\
\hline Navigation & $\begin{array}{l}0.26 \\
7\end{array}$ & 0.045 & 0.265 & $\begin{array}{l}5.97 \\
2\end{array}$ & $\begin{array}{l}.00 \\
0\end{array}$ & 0.501 & $\begin{array}{l}1.99 \\
6\end{array}$ \\
\hline $\begin{array}{l}\text { Personalizat } \\
\text { ion }\end{array}$ & $\begin{array}{l}0.19 \\
1\end{array}$ & 0.036 & 0.215 & $\begin{array}{l}5.34 \\
4\end{array}$ & $\begin{array}{l}.00 \\
0\end{array}$ & 0.606 & $\begin{array}{l}1.65 \\
0\end{array}$ \\
\hline
\end{tabular}

** Dependent Variable: e-service satisfaction

In addition to that, the results of Oliveira (2004) showed that e-service capability is a second-order factor that is reflected by the company's capabilities of e-service recovery, ease of navigation, service portfolio comprehensiveness, ecustomization and information richness. At the end, the findings of Gallant, Irizarry and Kreps (2007) showed that personalization is one of the vital factors for people in the adoption of hospital website usage.

\section{Conclusions}

The main objective of this study was to explore the impact of website design, navigation and personalization on e-service satisfaction. The reached results revealed that higher the perceived quality of university's website design, navigation and personalization, more the satisfaction in eservice occurs. Therefore, universities should focus on distinguished design characteristics such as creativity, consistency, organization of titles and subtitles and the balanced distribution of the diverse website content.

Besides that, universities should make it easy for their website to the accessed, searched and navigated with no disconnectedness by providing communication tools such as e-mail, chatting and evaluation forms to attract visitors, encourage them to stay as long as they can and come back again to do more transactions, which increase their satisfaction in e-service. 
As the e-business is increasing drastically in business environment nowadays, the need to enhance satisfaction in e-service will also increase. Practitioners and academics should align their efforts to sense and respond to new opportunities and threats in their industry.

\section{Limitations}

This study suffers from two main limitations. First, the sample employed student subjects, which may not be representative of the general population of online businesses. It is unclear whether the analytical results can be generalized to other online businesses. Further research can apply the research model to examine other types of online businesses.

Second, since the sample was collected in Jordan, generalizability to other countries might be limited due to cultural differences in website quality and e-satisfaction.

\section{Implications}

The results of this study have implications for practitioners. This study shows how the website design, navigation and personalization play a crucial role in the overall evaluation of e-service satisfaction. Based on the analysis of this study, it can be concluded that students' evaluation of website design, navigation and personalization can bias future evaluations of outcome e-service quality.

Management of universities need to be aware that a bad experience with website design, navigation and personalization can affect satisfaction If a student has a bad experience regarding interactivity, customization or website design, then a student might make an overall e-service quality judgment even before a transaction can take place. If customers believe that an organization's website is hard to use, is poorly designed, and doesn't take into consideration distinguished services for each user, then customers are likely to move to other organizations' websites.

There are several avenues of future research. The following questions still need to be answered: What other factors could impact e-service satisfaction within education context? Is e-service satisfaction affected by students' demographic variables? This is because of the wide customer reach of the internet channel, a website is typically exposed to a large number of customers with different personal profiles (Olson and Boyer, 2005; Boyer et al., 2002), including demographic and behavioral attributes. Therefore, there is a high likelihood of heterogeneity in customer requirements. In addition, a great deal of information about personal customer profiles can be generated and processed automatically at a low cost in eservices due to the internet data exchange between providers and customers (Sousa, Yeung and Cheng, 2008). As a result, it is relatively easy to make use of this information for alignment decisions. Second, as the growth of the internet and ebusinesses continue, future research can extend this research to other online businesses, measuring determinants of esatisfaction within other business contexts. Third, although the scales used for measuring dimensions of e-satisfaction are similar to existing scales, further research might consider developing more elaborate and richer measures for richer esatisfaction. Finally, evidence exists that the relative importance and possible meaning of e-satisfaction and website quality may differ across cultures (Tsikriktsis, 2002; Gefen, 2000). Thus, the study can be replicated in different cultures.

\section{Acknowledgments}

The researchers are grateful to Petra University in Jordan for sponsoring their visiting research fellow during the summer semester of the academic year 2009/2010 at The George Washington University in Washington DC, USA.

\section{References}

AL-Faouri, A. \& AL-Kasasbeh, M. (2010). 'The Influence of Aviation Companies' Perceived Websites Quality on E-trust: An Exploratory Study,' Proceedings of Aviation Information Technology, Engineering and Management 2010 Conference, March 2224, 2010. New Orleans, Louisiana, USA. 
Barnes, S. J. \& Vidgen, R. T. (2002). “An Integrative Approach to The Assessment of E-Commerce Quality," Journal of Electronic Commerce, 3: 114-127.

Chen, L.-D., Gillenson, M. L. \& Sherrell, D. L. (2002). "Enticing Online Consumers: An Extended Technology Acceptance Perspective," Information \& Management, 39: $705-719$

Chen L.-D., Soliman, K. S., Mao, E. \& Frolick, M. N. (2000). "Measuring User Satisfaction with Data Warehouses: An Exploratory Study," Information \& Management, 37(3): 103-110.

Chen, P.-Y. \& Hitt, L. M. (2002). “Measuring Switching Costs and the Determinants of Customer Retention in Internet-Enabled Businesses: A Study of the Online Brokerage Industry," Information Systems Research, 13(3): 255-274.

Cheung, C. M. K. \& Lee, M. K. 0. (2004/2005). "The Asymmetric Effect of Website Attribute Performance on Web Satisfaction: An Empirical Study," E-Service Journal, 3(3): 65-90.

Cho, N. \& Park, S. (2001). “Development of Electronic Commerce User - Consumer Satisfaction Index (ECUSI) for Internet Shopping," Industrial Management and Data Systems, 101(8): 400-405.

Cristobal, E., Flavian, C. \& Guinalıu, M. (2007). "Perceived E-Service Quality: Measurement Validation and Effects on Consumer Satisfaction and Website Loyalty," Managing Service Quality, 17(3): 317-340.

Cronin, J. J., Brady, M. K. \& Hult, G. T. M. (2000). "Assessing the Effects of Quality, Value and Customer Satisfaction on Consumer Behavioral Intentions in Service Environments," Journal of Retailing, 76(2): 193-218.

Cyr, D. (2008). "Modeling Website Design across Cultures: Relationships to Trust, Satisfaction and E-loyalty," Journal of Management Information Systems, 24 (4): 47-72.
Ethier, J., Hadaya, P., Talbot, J. \& Cadieux, J. (2006). "B2C Website Quality and Emotions during Online Shopping Episodes: An Empirical Study," Information \& Management, 43:627-639.

Evanschitzky, H., Iyer, G. R., Hesse, R. J. \& Ahlert, D. (2004). "E-satisfaction: A ReExamination," Journal of Retailing, 80: 239. 247.

Gallant, L., Irizarry, C. \& Kreps, G. L. (2007). "User-Centric Hospital Websites: A Case for Trust and Personalization," E- Service Journal, 5(2): 5- 26.

Gefen, D. (2000). "E-commerce: The Role of Familiarity and Trust," OMEGA the International Journal of Management Science, 28(6): 725-737.

Gefen, D. (2002). "Customer Loyalty in ECommerce," Journal of the Association for Information Systems, (3)1: 27-51.

Greer, T. H. \& Murtaza, M. B. (2003) 'Web Personalization: The Impact of Perceived Innovation Characteristics on the Intention to Use Personalization,' Journal of Computer Information Systems, 50-53.

Ha, H.-Y. (2004). "Factors Influencing Consumer Perceptions of Brand Trust Online," Journal of Product and Brand Management, 13 (5): 329-342.

Hair, J. F., Anderson, R. E., Tatham, R. L. \& Black, W. C. (1995). Multivariate Data Analysis with Readings, Englewood Cliffs, NJ: Prentice Hall.

Hallerman, D. (2009). 'Websites,' Consumer Marketing: 213 -216.

Hernandez, B., Jimenez, J. \& Martin, M. J. (2009). "Key Website Factors in E-Business Strategy," International Journal of Information Management, 29(5): 362-371.

Janda, S., Trocchia, P. J. \& Gwinner, K. P. (2002). "Consumer Perceptions of Internet Retail Service Quality," International Journal of Service Industry Management, 13(5): 412-431. 
Jayawardhena, C. \& Foley, P. (2000). "Changes in Banking Sector: The Case of Internet Banking in UK," Journal of Internet Research: Networking and Policy, 10(1):1930.

Kim, S. \& Lee, Y. (2006). "Global Online Marketplace: A Cross-Cultural Comparison of Website Quality," International Journal of Consumer Studies, 30(6): 533-543.

Lee, G.-G. \& Lin, .H.-F. (2005). "Customer Perceptions of E-Service Quality in Online Shopping," International Journal of Retail and Distribution Management, 33 (2/3): 161-177.

Lin, J. C.-C. (2007). "Online Stickiness: Its Antecedents and Effect on Purchasing Intention," Behaviour and Information Technology, 26(6): 507 - 516.

Lin, J. C.-C. \& Lu, H. (2000). "Towards an Understanding of the Behavioral Intention to Use a Website," International Journal of Information Management, 20:197-208.

Loiacono, E. T., Chen, D. O. \& Goodhue, D. L. (2002). "WebQualTM Revisited: Predicting the Intent to Reuse a Website," Proceedings of the International Conference on Information Systems, Barcelona, Spain, December 15-18.

Madu, C. N. \& Madu, A. A. (2002). "Dimensions of E-quality," International Journal of Quality and Reliability Management, 19(3): 246-258.

McIntire, P. (2008). 'Visual Design for the Modern Web,' Indianapolis, IN: New Riders.

Moon, J. W. \& Kim, Y.-G. (2001). "Extending the Tam for a World-Wide-Web Context," Information \& Management, 38: 217 - 230.

Nielsen, J. (2000). 'Designing Web Usability,' Indianapolis, IN: New Riders.

Novak, T. P., Hofftnan, D. L. \& Yung, Y.-F. (2000). "Measuring the Customer Experience in Online Environments: A Structural Modeling Approach," Marketing Science, 19(1): 22-42.
Oliveira, P. (2004). 'An Empirical Investigation of the Antecedents and Consequences of B2B E-Service Capability,' $\mathrm{PhD}$ thesis, The University of North Carolina at Chapel Hill.

Olson, J. R. \& Boyer, K. K. (2005). "Internet Ticketing in a Not-For-Profit, Service Organization: Building Customer Loyalty," International Journal of Operations and Production Management, 25(1): 74-92.

Pallant, J. (2001). 'SPSS Survival Manual: A Step by Step to Data Analysis Using SPSS,' Allen and Unwin, Australia.

Pallas, J. \& Economides, A. A. (2008). "Evaluation of Art Museums' Web Sites Worldwide," Information Services and Use, 28: 45-57.

Palmer, J. W. (2002). "Website Usability, Design, and Performance Metrics," Information Systems Research, 13(2): 151167.

Reichheld, F. F. \& Schefter, P. (2000). "ELoyalty: Your Secret Weapon on the Web," Harvard Business Review, 78 (4): 105-113.

Ribbink, D., van Riel, A. C. R., Liljander, V. \& Treukens, S. (2004). "Comfort your Online Customer: Quality, Trust and Loyalty on the Internet," Managing Service Quality, 14 (6): 446-456.

Santos, J. (2003). "E-service Quality: A Model of Virtual Service Quality Dimensions," Management Service Quality, 13(3): 233-246.

Sekaran, U. \& Bougie, R. (2010). Research Methods for Business: A Skill Building Approach, 5th edition, John Wiley and Sons, Inc.

Siu, N. Y.-M., Zhang, J.-F. \& Lam, Y. Y. (2010). "Electronic Service Quality and Routes to Site Commitment: The Case of an Online Film Ticketing Service," Journal of International Consumer Marketing, 22(3): 293-307. 
Szymanski, D., M. \& Hise, R. T. (2000). "Esatisfaction: An Initial Examination," Journal of Retailing, 76(3): 309-322.

Sousa, R., Yeung, A. C. L. \& Cheng, T. C. E. (2008). "Customer Heterogeneity in Operational E-Service Design Attributes: An Empirical Investigation of Service Quality," International Journal of Operations and Production Management, 28 (7): 592614.

Sukasame, N. (2005). "E-Service Quality: A Paradigm for Competitive Success of ECommerce Entrepreneurs," Pacific Asia Conference on Information Systems PACIS 2005, Bangkok, Thailand.

Tan, C. W. \& Benbasat, I. (2009). "T Mediated Customer Services in EGovernment: A Citizen's Perspective," Communications of the Association for Information Systems, 24(12): 175-198.

Tan, F. B., Tung, L.-L. \& Xu, Y. (2009). "Study of Web-designers' Criteria for Effective Business-to-Consumer Websites Using the Repertory Grid Technique," Journal of Electronic Commerce Research, 10(3): 155178.

Tarafdar, M. \& Zhang, J. (2006). 'Analysis of Critical Website Characteristics: A CrossCategory Study of Successful Websites,' Journal of Computer Information Systems, 46(2): 14-24.

Tarafdar, M. \& Zhang, J. (2008). "Determinants of Reach and Loyalty: A Study of Website Performance and Implications for Website Design," Journal of Computer Information Systems: 16-24.

Tsikriktsis, N. (2002). "Does Culture Influence Website Quality Expectations? An Empirical Study," Journal of Service Research, 5(2): 101-112.

Vijayasarathy, L. R. (2004). "Predicting Consumer Intentions to Use On-Line Shopping: The Case For An Augmented Technology Acceptance Model," Information \& Management, 41: 747-762.
Wahab, S., Al-Momani, K. \& Noor, A. M. (2010). "The Relationship between EService Quality and Ease of Use on Customer Relationship Management (CRM) Performance: An Empirical Investigation In Jordan Mobile Phone Services," Journal of Internet Banking and Commerce, 15(1): 115.

Wakefield, R. J., Stocks, M. H. \& Wilder, W. M. (2004). 'The Role of Website Characteristics in Initial Trust Formation,' Journal of Computer Information Systems, 45 (1): 94-103.

Xiao, L. \& Dasgupta, S. (2005). "User Satisfaction with Web Portals: An Empirical Study," In Web Systems Design and Online Consumer Behavior by Gao, Y. (Ed.). Idea Group Publishing, Hershey, PA: 192-204.

Yang, Z. (2001). 'Customer Perceptions of Service Quality in Internet-Based Electronic Commerce,' Proceedings of the 30th EMAC Conference, Bergen: 8-11.

Zeithaml, V. A. (2002). "Service Excellence in Electronic Channels," Managing Service Quality, 12(3): 135-138.

Zeithaml, V. A., Parasuraman, A. \& Malhotra, A. (2002). "Service Quality Delivery through Websites: A Critical Review of Extant Knowledge," Journal of the Academy of Marketing Science, 30(4): 362-375.

http://www.uop.edu.jo/News/?lang=enan d location $=$ aboutand nid $=541$, [Retrieved: August, 01, 2010]

http://www.webometrics.info/top12000.a sp?offset=4346, [Retrieved: August, 01, 2010] 